\title{
CONFIRMED RECORD OF THE GENUS CHERNES IN BOSNIA AND HERZEGOVINA (PSEUDOSCORPIONES: CHERNETIDAE)
}

\author{
Jana Christophoryová*, Martina Červená \& \\ Katarína Krajčovičová
}

Department of Zoology, Faculty of Natural Sciences, Comenius University, Mlynská dolina, Ilkovičova 6, SK-842 15 Bratislava, Slovakia

Christophoryová, J., Červená, M. \& Krajčovičová, K.: Confirmed record of the genus Chernes in Bosnia and Herzegovina (Pseudoscorpiones: Chernetidae). Nat. Croat., Vol. 27, No. 1, 233-237, Zagreb, 2018.

The finding of the chernetid pseudoscorpion Chernes hahnii (C.L. Koch, 1839) represents the first reliable record of the genus Chernes Menge, 1855 in Bosnia and Herzegovina. Adults, as well as nymphal stages were collected from six localities and occurred under bark of trees.

Key words: Balkans, Chernes hahnii, confirmed record, pseudoscorpion, tree bark

Christophoryová, J., Červená, M. \& Krajčovičová, K.: Potvrđeni nalaz roda Chernes u Bosni i Hercegovini (Pseudoscorpiones: Chernetidae). Nat. Croat., Vol. 27, No. 1, 233-237, Zagreb, 2018.

Nalaz pseudoškorpiona iz porodice Chernetidae Chernes hahnii (C.L. Koch, 1839) prvi je sigurni nalaz roda Chernes Menge, 1855 u Bosni i Hercegovini. Odrasli primjerci, kao i stadiji nimfe, prikupljeni su sa šest lokaliteta, ispod kore drveća.

Ključne riječi: Balkan, Chernes hahnii, potvrđeni nalaz, pseudoškorpioni, kora drveta

\section{INTRODUCTION}

According to the world pseudoscorpion catalogue, 55 species are known from Bosnia and Herzegovina (Harvey, 2013). Most of them belong to the families of Chthoniidae and Neobisiidae. The species Pselaphochernes hadzii Curčić, 1972, P. lacertosus (L. Koch, 1873), Dinocheirus panzeri (C.L. Koch, 1837), Allochernes wideri (C.L. Koch, 1843) with the subspecies $A$. wideri phaleratus (Simon, 1879) from the family Chernetidae have been recorded in Bosnia and Herzegovina (HARveY, 2013) in the catalogue did not mention two others chernetid species from BEIER (1929) - Lamprochernes nodosus (Schrank, 1803) and Pselaphochernes scorpioides (Hermann, 1804). Chernetid species have low known diversity not only in Bosnia, but across the Balkans in generally (Christophoryová \& JABLONSKI, 2017). The present findings of Chernes hahnii (C.L. Koch, 1839) represent the first reliable record of the species, and the genus as well, in Bosnia and Herzegovina. In the Balkans, the species has been known to occur only in Bulgaria (HARveY, 2013); quotation from Bosnia by Beier (1929) is doubtful, since it may be referred also to Chernes cimicoides (Fabricius, 1793).

\footnotetext{
* Corresponding author: Jana Christophoryová; e-mail: christophoryova@gmail.com
} 


\section{MATERIAL AND METHOD}

During two excursions in 2017 to Bosnia and Herzegovina, 99 specimens of Chernes hahnii were collected under tree bark. The specimens were studied as temporary slide mounts using lactic acid as a medium, then first rinsed in water and returned to $70 \%$ ethanol. The species was photographed using a Leica DM1000 compound microscope with ICC50 Camera Module (LAS EZ application, 1.8.0). The specimens were identified using the identification keys proposed by BeIER (1963) and Christophoryoví et al. (2011b) and they are deposited in the zoological collections of Comenius University, Bratislava.

List of localities (Figs 1, 2)

1. Trebinje, $42.70866^{\circ} \mathrm{N}, 18.34282^{\circ} \mathrm{E}, 264 \mathrm{~m}$ a. s. 1., alley near bus station, under bark of Platanus acerifolia

2. Sarajevo, Lukavica, $43.81561944^{\circ} \mathrm{N}, 18.34921389^{\circ} \mathrm{E}, 518 \mathrm{~m}$ a. s. l., garden near the restaurant, under bark of Platanus sp.

3. Sarajevo, At Mejdan, $43.85708^{\circ}$ N, $18.42774^{\circ}$ E, 555 m a. s. 1., city park, under bark of Platanus sp.

4. Sarajevo, Alifakovac, $43.85821111^{\circ}$ N, $18.43698889^{\circ}$ E, $580 \mathrm{~m}$ a. s. 1., cemetery, under bark of Betula sp.

5. Tuzla, Gradski park, $44.53848611^{\circ} \mathrm{N}, 18.67936111^{\circ} \mathrm{E}, 230 \mathrm{~m}$ a. s. l., city park, under bark of Platanus acerifolia

6. Tuzla, $44.53990^{\circ} \mathrm{N}, 18.66499^{\circ}$ E, $224 \mathrm{~m}$ a. s. 1., city park, under bark of Platanus acerifolia.

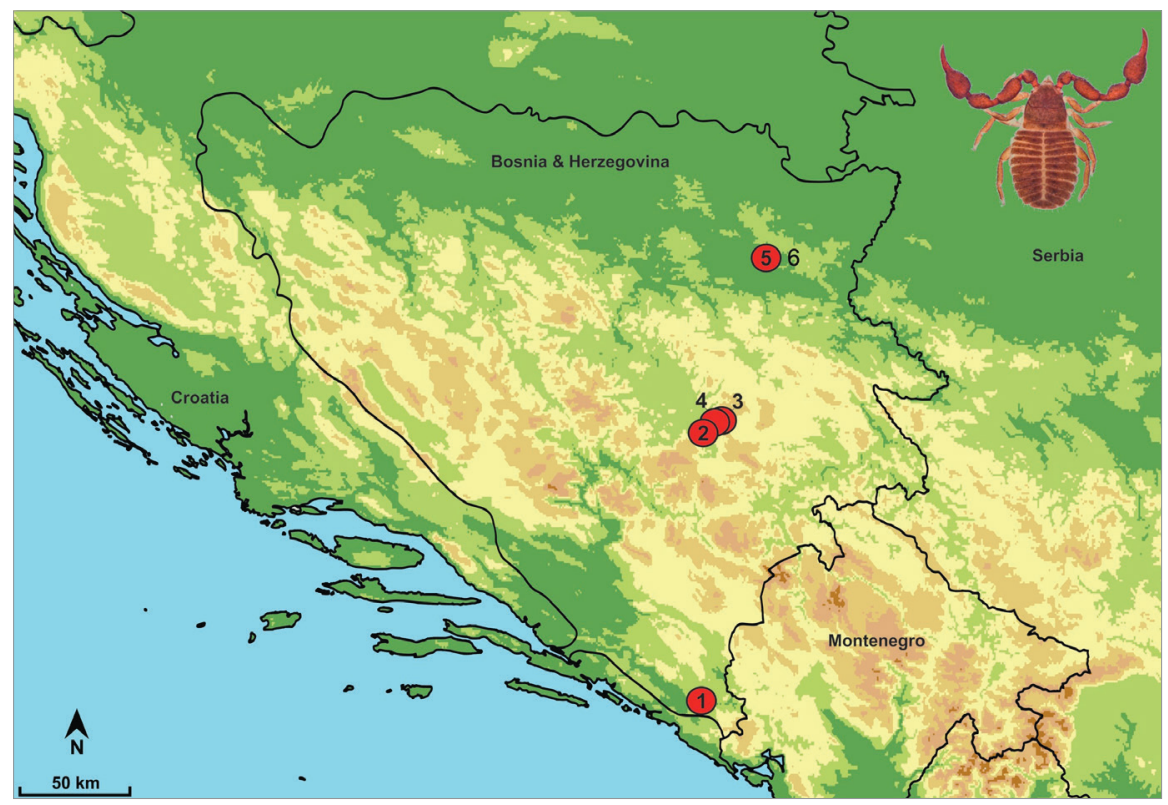

Fig. 1. Map of Bosnia and Herzegovina showing records of Chernes hahnii. For locality codes see Material and Method. 

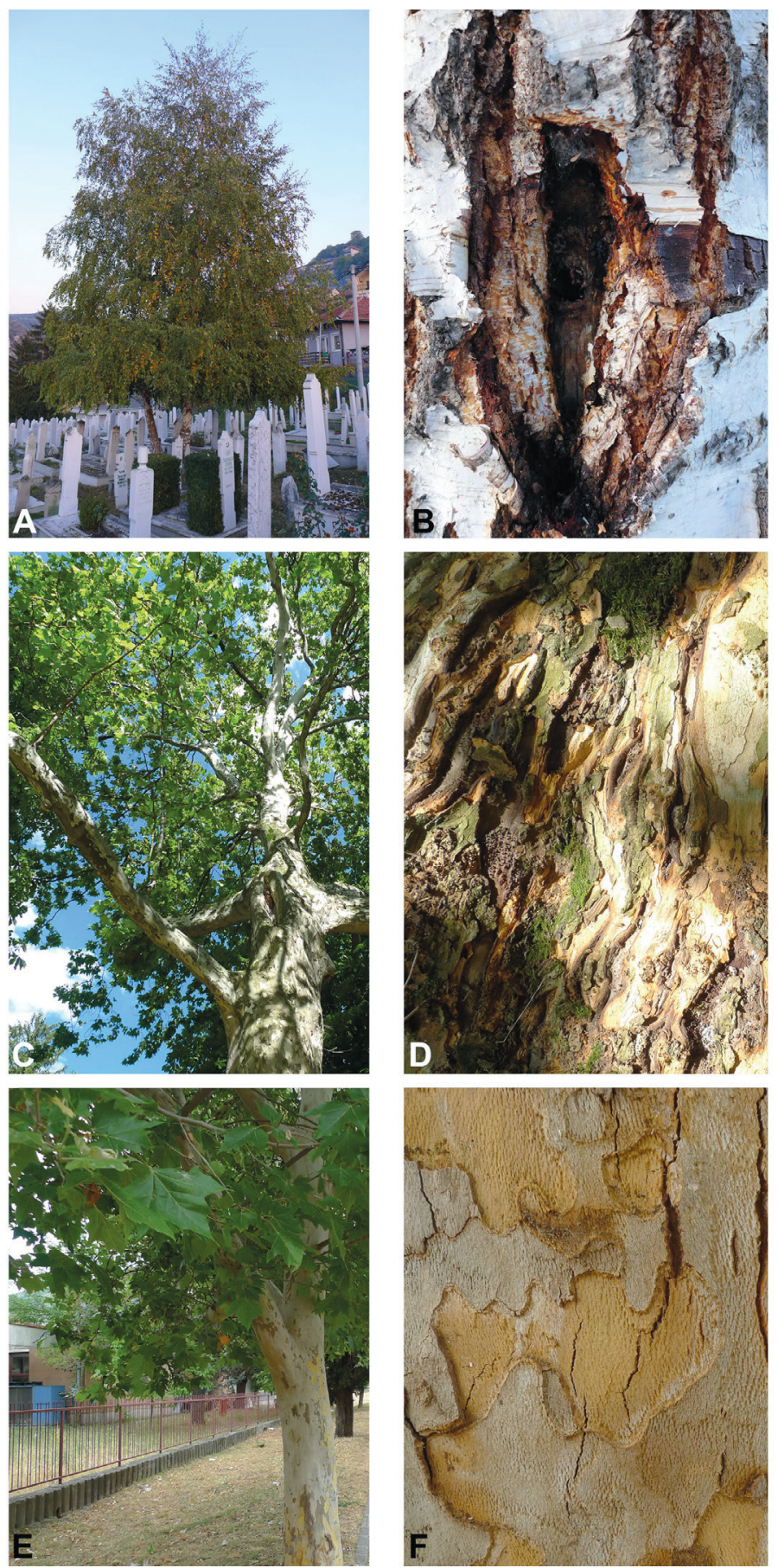

Fig. 2. Habitat and microhabitat types of Chernes hahnii in Bosnia and Herzegovina. A, B: Betula sp. at the cemetery (Locality 4, see Material and Method); C, D: Platanus sp. in the park (Locality 3); E, F: Platanus acerifolia in alley (Locality 1). 


\section{RESULTS AND DISCUSSION}

\section{Chernes hahnii (C.L. Koch, 1839) (Fig. 3)}

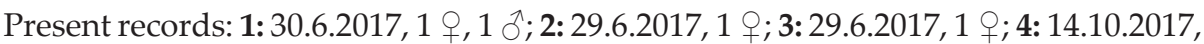

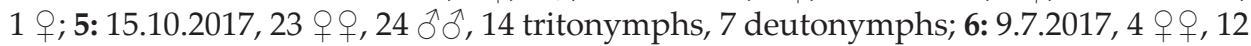
$\widehat{\jmath} \hat{o}, 10$ tritonymphs.

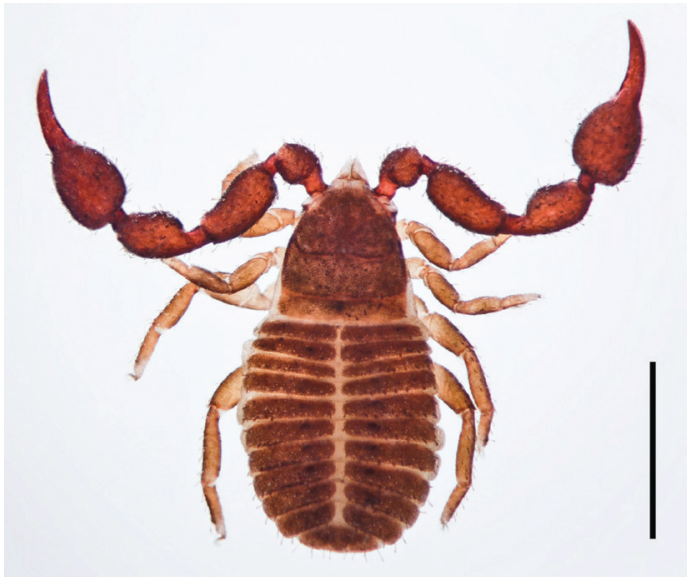

Fig. 3. Male of Chernes hahnii. Scale line: $1 \mathrm{~mm}$.

Presented specimens of $C$. hahnii were found under tree bark. No other pseudoscorpion species were collected in the studied microhabitat at the selected localities. During the months of collecting, silken chambers of the species were present under the tree barks. In July females with eggs were collected.

BEIER (1963) reported that the species is typically an inhabitant of the space under the bark of the broad-leaved trees. In later studies its strong association with the microhabitat under tree bark was confirmed (ŠŤÁHLAvsKÝ, 2001; KRAJČovičovÁ \& CHRISTOPHORYOvÁ, 2014). In addition, it can be found in other tree microhabitats, such as tree hollows, dead wood and directly on tree bark (Christophoryoví et al., 2017). Except for tree microhabitats $C$. hahnii is known to be an inhabitant of bird nests (TuRIENzo et al., 2010; Christophoryová et al., 2011a). The new findings correspond with the known microhabitat preference of the species.

A basic identification key to chernetid taxa known from Bosnia and Herzegovina is given (Beier, 1963; Ćurćić, 1972; Christophoryová et al., 2011b, Christophoryová \& JABLONSKI, 2017):

1 Body and palpal setae long, pointed and finely toothed ...Lamprochernes nodosus

- Body and palpal setae short, dentate and clavate.................. 2

2 Pedal tarsus IV with a long tactile seta distinctly longer than the width of

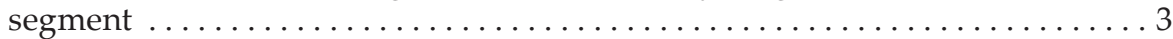

- Pedal tarsus IV with tactile seta absent or with a short distal pseudotactile seta . 5

3 Palpal femur at most $0.59 \mathrm{~mm}$ long, palpal patella at most $0.52 \mathrm{~mm}$ long. . . . . 4

- Palpal femur 0.58-0.65 mm long, palpal patella $0.57-0.67 \mathrm{~mm}$ long 
4 Palpal femur $0.43-0.59 \mathrm{~mm}$ long, palpal patella $0.43-0.52 \mathrm{~mm}$ long $\ldots \ldots \ldots \ldots \ldots \ldots \ldots \ldots \ldots \ldots \ldots \ldots \ldots \ldots \ldots \ldots \ldots$ Pselaphochernes scorpioides

- Palpal femur 0.48-0.54 mm long, palpal patella 0.45-0.47 $\mathrm{mm}$ long

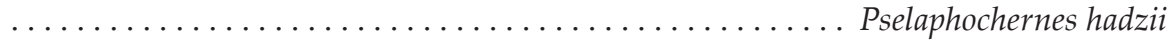

5 Pedal tarsus IV with a subdistal pseudotactile seta; tergite XI with a pair of long tactile setae; female spermatheca paired, with a pair of long tubes with terminal

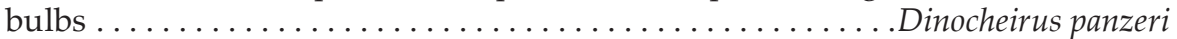

- Pedal tarsus IV without pseudotactile seta; tergite XI without a pair of long

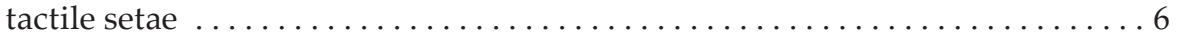

6 Number of accessory teeth of chelal fingers reduced: movable chelal finger medially with only 1 accessory tooth; female spermatheca unpaired, T- or mushroom-

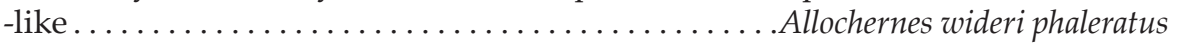

- Number of accessory teeth of chelal fingers not reduced: movable chelal finger medially with 4-7 accessory teeth; female spermatheca paired, with long and

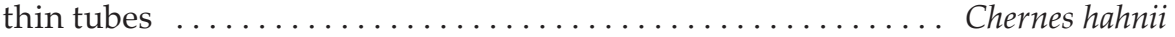

\section{ACKNOWLEDGMENTS}

We are very thankful to Daniel Jablonski and Daniel Grul'a (Slovakia) for their technical assistance with the figures and Alica and Zuzana Christophoryová for their help during the fieldwork. We would like to thank our colleagues Giulio Gardini (Italy) and Juan A. Zaragoza (Spain) for all their corrections and comments, which greatly improved our manuscript. The study was financially supported by the project VEGA 1/0191/15.

Received January 10, 2018

\section{REFERENCES}

Beier, M., 1929: Die Pseudoskorpione des Wiener Naturhistorischen Museums. II. Panctenodactyli. Annalen des Naturhistorischen Museums in Wien 43, 341-367.

BeIER, M., 1963: Ordnung Pseudoscorpionidea (Afterskorpione). Bestimmungsbücher zur Bodenfauna Europas. Vol. 1. Akademie-Verlag, Berlin.

Christophoryová, J. \& Jablonski, D., 2017: New data concerning the distribution of pseudoscorpions in Albania (Pseudoscorpiones: Chernetidae). Natura Croatica 26(1), 117-122.

Christophoryová, J., JajCayová, D. \& Krajčovičová, K., 2017: Pseudoscorpions (Arachnida: Pseudoscorpiones) living in tree microhabitats in Slovakia. Klapalekiana 53, 283-297.

Christophoryová, J., Krumpálová, Z., Krištofík, J. \& Országhová, Z., 2011a: Association of pseudoscorpions with different type of bird nests. Biologia 66(4), 669-677.

Christophoryová, J., ŠŤÁHLAvskŕ, F. \& Fedor, P., 2011b: An updated identification key to the pseudoscorpions (Arachnida: Pseudoscorpiones) of the Czech Republic and Slovakia. Zootaxa 2876, 35-48.

Ćurčıć, B. P. M., 1972: Pselaphochernes hadzii, nouveau pseudoscorpion des montagnes du sud-est de la Bosnie. Razprave Slovenska Akademija Znanosti in Umetnosti 15, 76-93.

Harvey, M. S., 2013: Pseudoscorpions of the World. Version 3.0. Western Australian Museum, Perth. Available from: http://museum.wa.gov.au/catalogues-beta/pseudoscorpions/ (Accessed at: 2018.01.10).

Krajčovičová, K. \& Christophoryová, J., 2014: Faunistic survey of pseudoscorpions (Arachnida: Pseudoscorpiones) collected from trees and using Malaise traps in Slovakia and the Czech Republic. Klapalekiana 50, 167-180.

ŠŤÁhlavský, F., 2001: Štírci (Arachnida: Pseudoscorpiones) Prahy. Klapalekiana 37, 73-121.

Turienzo, P., Di Iorio, O. \& Mahnert, V., 2010: Global checklist of pseudoscorpions (Arachnida) found in birds ' nests. Revue suisse de Zoologie 117(4), 557-598. 
